\title{
Effects of storage structures and moisture contents on seed quality attributes of quality protein maize
}

\author{
Gopal Bhandari $^{*}$, Tara Bahadur Ghimire ${ }^{1}$, Sangita Kaduwal ${ }^{1}$, Jiban \\ Shrestha ${ }^{2}$, Ramesh Acharya ${ }^{3}$ \\ ${ }^{1}$ Nepal Agricultural Research Council (NARC), Seed Science and Technology \\ Division (SSTD), Khumaltar, Lalitpur \\ ${ }^{2}$ National Maize research Program (NMRP), Rampur, Chitwan \\ ${ }^{3}$ Nepal Agricultural Research Council (NARC), Agri-Botany Division (ABD), \\ Khumaltar, Lalitpur \\ ${ }^{1 *}$ Corresponding author's email: gopal.bhandari@narc. gov.np \\ *ORCID ID: https://orcid.org/0000-0001-9858-2026
}

Received: August 21, 2017; Revised: October 18, 2017; Accepted: December 22, 2017

(C) Copyright 2017 Bhandari et al.

This work is licensed under a Creative Commons Attribution-Non-Commercial 4.0 International License.

\begin{abstract}
The study was aimed to examine the effects of various storage structures and moisture contents on seed quality attributes of quality protein maize seed. The quality protein maize (QPM-1) seed was tested in conventional seed storage containers (Fertilizer sack and earthen pot) and the improved hermetic ones (Metal bin, Super grain bag, and Purdue Improved Crop Storage (PICS) bag) at Seed Science and Technology Division, Khumaltar, Nepal during February, 2015 to January 2016. Ten treatments comprising 5 storage devices in two moisture regimes (11\% and 9\%) replicated thrice and laid out in Completely Randomized Design (CRD). Data on temperature, relative humidity $(\mathrm{RH})$, germination, electrical conductivity (EC), seed moisture content (MC) were collected bimonthly. The conventional containers were found liable to the external environmental condition whereas the hermetic structures observed with controlled RH level below $40 \%$ in all combinations. Electrical conductivity (EC) for seed vigor showed that hermetic containers provide higher seed vigor than the conventional ones. Up to 4 months all treatments were found statistically at par for germination. A significant difference was observed in each treatment after 4 months where PICS bag \& Super grain bag showed best germination followed by metal bin while fertilizer bag \& earthen-pot showed poorer and poorest germination respectively till one year. Almost all treatments with lower MC showed better results than the treatments with higher MC. A negative correlation $\left(R^{2}=69.7 \%\right)$ was found between $\mathrm{EC}$ and Germination. All six figures from 2 to 12 months on MC showed statistically different where hermetic plastic bags were found maintaining MC as initial whereas MC of fertilizer bags and earthen pot was spiked than the basal figure. The finding evidenced that the hermetic containers and low MC are the seed storage approaches for retaining the quality of seed even in an ambient environmental condition for more than a year.
\end{abstract}

Keywords: Seed quality, Germination, storage containers, Electrical conductivity, Moisture content

Correct citation: Bhandari, G., Ghimire, T. B., Kaduwal, S., Shrestha, J., \& Acharya, R. (2017). Effects of storage structures and moisture contents on seed quality attributes of quality protein Maize. Journal of Maize Research and Development, 3 (1), 77-85. doi: http://dx.doi.org/10.3126/jmrd.v3i1.18924 


\section{Journal of Maize Research and Development (2017) 3 (1):77-85 \\ ISSN: 2467-9291 (Print), 2467-9305 (Online) \\ DOI: http://dx.doi.org/10.3126/jmrd.v3i1.18924}

\section{INTRODUCTION}

Maize (Zea mays L.) is the second most important staple food crop after rice and a major feed crop in Nepal (KC et al., 2015). Despite the implementation of various seed related projects and active involvement of public and private institutions; still the country has been suffering from unavailability of quality seeds. Quality seed demand in Nepal is apparently tremendous, where lion's share of seeds are imported and country's import has been hiking each year. The official record of Seed Quality Control Centre (SQCC) in 2015 shows that 2745 metric tons of seed was traded in where 1025 million of Nepalese currency redeemed. Formal sector contributes less than $10 \%$ of seed demand whereas Informal sector, farmer-to-farmer seed exchange mechanism has been contributing 20-50\% of seed demand. Seed replacement rate (SRR) for maize is below 15 $\%$ (Joshi, 2015). Hence, production and proper storage of quality seed in community level is regarded as pivotal step for ameliorating the quality seed scarcity.

Seed is a fragile living entity; hence storability is greatly influenced by the subjected abiotic and biotic environmental conditions. The principal environmental factor that is responsible for seed quality deterioration are temperature, relative humidity, atmospheric conditions of storage containers and moisture content of the seed. The hygroscopic nature of maize seed sometimes make them unsafe for storage in open container (Adetumbi et al., 2009). In humid tropical region, at temperature $25^{\circ} \mathrm{C}$ and above and $65-70 \%$ relative humidity, storage of maize seed for more than 3-4 months could be detrimental for seed viability and vigor unless proper container and moisture level maintained (Abba \& Lavato, 1999). Moreover, Maize weevil (Sitophilus zeamais Mostsch.) and Angoumois grain moth (Sitotroga cerealella Oliv.) were major insect pests found as limitations to be considered in maize storage in Nepal (Sherpa et al., 1997, G.C., 2006). Similarly, 10-20\% quantitative loss of maize is recorded during storage in western Nepal due to poor storage technique that incite deterioration of viability and vigor of maize seed (Bhandari et al., 2015).

Seed quality, viz. viability and vigor decreases under long storage conditions due to ageing. The relationship between laboratory and field germination depends directly on environmental conditions and procedures adopted for field sowing. The capacity of laboratory tests estimating field seedling emergence potential inversely related with ideal environmental conditions, and sometimes becomes null under extremely unfavorable conditions (Egli \& TeKrony, 1996). The EC test is one of those used to evaluate the seed vigor. The relationship between water content, organizational level of seed cellular membranes and quantity of leachates in the soaking solution serve as the theoretic base of the EC test. Thus, lower the amount of leachates released to the soaking solution, indicates high seed vigor and vice versa (Adriana et al., 2012; Powell, 1988). Unlike germination and Accelerated Ageing Test, the conductivity test can be conducted within 24 hours with an instrument in field level which is regarded as easy and effective method to assess the quality of seed lot rapidly with reliability (Bewley \& Black, 1994). Studies with pea, soybean, cotton, Phaseolus bean, maize and small- seeded crops found that seed leachate conductivity test indicates both standard germination and seed vigor in reliable way (Matthews \& Powell 2006). 
Journal of Maize Research and Development (2017) 3 (1):77-85

ISSN: 2467-9291 (Print), 2467-9305 (Online)

DOI: http://dx.doi.org/10.3126/jmrd.v3i1.18924

Besides quality seed supply, the environment and pests are the major cons for maintaining the proper seed quality for longer period. This experiment was thus designed to evaluate the functionality of existing common seed storage devices, earthen pot and plastic sacks with improved ones, metal bin, Super grain bag, and PICS bag.

\section{MATERIALS AND METHODS}

The experiment was conducted in laboratory of Seed Science and Technology Division (Longitude $85^{\circ} 10^{\prime}$ E and Latitude $27^{\circ} 39^{\prime} \mathrm{N}$; Altitude, 1335m), Nepal during February 2015 to January, 2016.

A maize variety, quality protein maize-1 (QPM-1) was selected and stored at two moisture regimes;

- M1: $11 \%$ moisture content

- M2: $9 \%$ moisture content

Moisture content of maize was maintained by applying initial sun drying method and further a week desiccation with the help of zeolite beads in a recommended amount using drying bead calculation software. Seed maintained at two different moisture regimes (M1 and M2) with 98\% initial germination were stored in five different storage containers as follows:

- S1:Metal Bin (Made up of 24 gauze plane zinc sheet)

- S2: Plastic sack or fertilizer bag (a high density polyethylene (HDPE) fertilizer bag with 100 gauge of low density polyethylene (LDPE) film laminated internally)

- S3: Super Grain Bags

- S4: Earthen pot or bin (locally called Ghyampo)

- S5: Purdue Improved Crop Storage (PICS) bag.

Ten treatments comprising 5 storage devices (S1, S2, S3, S4, and S5) in each seed moisture regime (moisture regimes M1 and M2) replicated thrice and laid out in Completely Randomized Design (CRD). A digital hygrometer was incorporated inside the each container in order to record the temperature and $\mathrm{RH}$ and all sets were stored in ambient condition. The initial seed quality attributes like germination, EC, and seed moisture content in each treatment were analyzed at every two months interval.

Hygrometer readings for temperature and RH were recorded just before sampling. Seed sampling from each treatment for germination, seed MC and EC was carried out in bimonthly interval. Germination was conducted in germination paper by using between paper (BP) methods. Oven method was used for the assessing the moisture content of the seed as described by ISTA (International Seed Testing Association) rule. The EC was checked and recorded randomly in three replications of each treatment. According to the method of seed vigor testing (ISTA, 2011), fifty seeds in each treatment were weighed and placed in $250 \mathrm{ml}$ distilled water containing beaker. Further, beakers were sealed using aluminum foil and was kept at $20^{\circ} \mathrm{C}$ for $24 \mathrm{~h}$. The electrical conductivity of the seed leachates was measured using Hanna's EC meter (HI 99300) and results of EC was expressed in $\mu$ Siemens $\mathrm{cm}^{-1} \mathrm{~g}^{-1}$, which was calculated formula.

$$
\mathrm{EC}\left(\mu \mathrm{Scm}^{-1} \mathrm{~g}^{-1}\right)=\frac{\text { Conductivity Reading }\left(\mu \mathrm{Scm}^{-1}\right) \text {-background reading }}{\text { Weight }(\mathrm{g}) \text { of replicate }}
$$


Journal of Maize Research and Development (2017) 3 (1):77-85

ISSN: 2467-9291 (Print), 2467-9305 (Online)

DOI: http://dx.doi.org/10.3126/jmrd.v3i1.18924

Data collected on various parameters were portrayed and analyzed by using MS-excel, Gen-stat and mean separation was done by Minitab.

\section{RESULTS AND DISCUSSION}

The hygrometer readings revealed that the temperature was more or less constant with respect to the storage room temperature that is $10-12^{\circ} \mathrm{C}$. Moreover, $\mathrm{RH}$ for the opened containers, viz. plastic sack and earthen bin also remained concurrent (around 70\%) with the ambient RH while the Metal bin, Super grain bag and PICS bags were found with controlled atmospheric environment internally where $\mathrm{RH}$ accounted for below $40 \%$ (Figure 1).

Fig 1: Variation of in-vitro Temperature $(\mathrm{oC})$ and $\mathrm{RH}(\%)$ after one year period in different storage containers and MC in Khumaltar, 2015-2016.

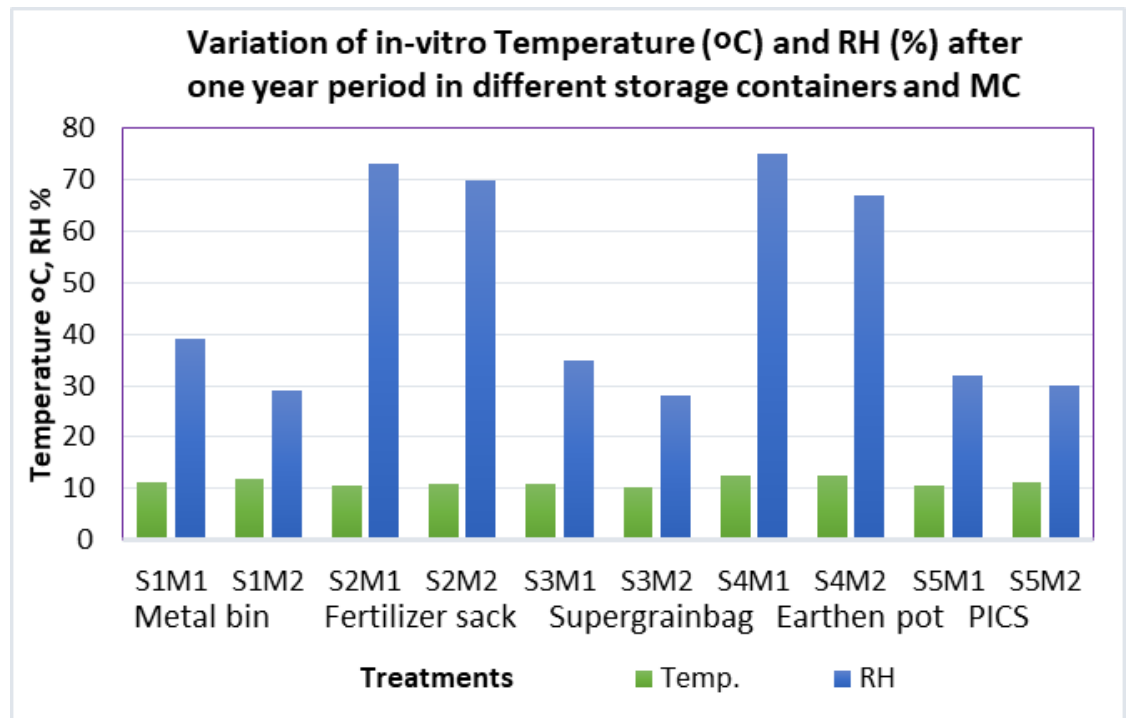

In addition to this, the $\mathrm{RH}$ for the hermetic containers with low MC was also found to be lesser RH than the same containers with higher MC\%.

This suggests that the hermetic containers meliorate the storability of seeds in low moisture content as per the thumb rule proposed by Harrington that the sum of temperature in Fahrenheit and $\mathrm{RH}$ in

percentage should be less than 100.The safe RH for seed storage is 40\% (Harrington,1960). So in the given $\mathrm{MC}$ and temperature, these hermetic containers were found better for mitigating the $\mathrm{RH} \%$ in humid sub-tropical climatic condition.At the storage of one year period, the electrical conductivity of stored maize seed in hermetic containers in below $60 \mu \mathrm{Scm}^{-1} \mathrm{~g}^{-1}$ were found significantly lower, whereas the conductivity for storage in fertilizer bag and earthen bin was found spiked beyond $140 \mu \mathrm{Scm}^{-1} \mathrm{~g}^{-1}$ with highly significant $(\mathrm{p} \leq 0.01$ ) (Figure 2). Unlike maize, Soybean seed lots that present EC test values between 60 and $70 \mu \mathrm{Scm}^{-1} \mathrm{~g}^{-1}$ are considered high vigor seed lots; values between 70 and $80 \mu \mathrm{Scm}^{-1} \mathrm{~g}^{-1}$ are presented by intermediary vigor seed lots (Vieira, 1994). On the other hand, in the United States of America, seeds with EC values higher than $150 \mu \mathrm{Scm}^{-1} \mathrm{~g}^{-1}$ are classified as low vigor seed lots and considered inadequate for sowing (AOSA, 1983). These figures bolstered the current finding to a convinced extent, although crop seed was different. 
Fig 2: Variation in Electrical conductivity in QPM seed after one year storage in various containers and MC in Khumaltar, 2015-2016.

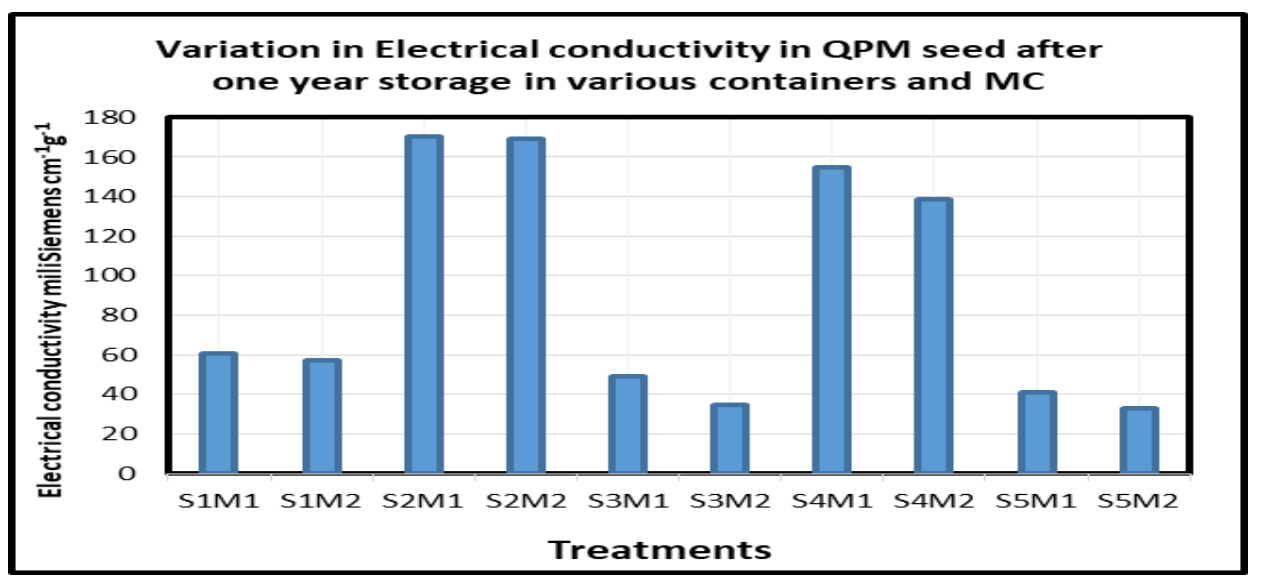

Significant difference was observed in the germination in QPM-1 among the 10 treatments after 4-months. Instead of diverse mean values among the treatments, no any statistical discrepancies were found until 4 months period. After 6-months, the germination was found statistically different in Ghyampo (S4), which revealed poor germination than other 4 structures and MC. In $8^{\text {th }}$ month, Metal bin (S1), super-grain bag (S3), and PICS (S5) showed superior germination than that of Fertilizer bag (S2) and Earthen pot (S4) similar trend was also seen in both results from $10^{\text {th }}$ and $12^{\text {th }}$ month (Table 1).

Table 1. Effect of storage structure and moisture content on germination in QPM-1 for yearlong storage in SSTD, Khumaltar, 2016.

\begin{tabular}{|c|c|c|c|c|c|c|c|}
\hline \multirow{2}{*}{$\begin{array}{l}\text { Ent } \\
\text { No. }\end{array}$} & \multirow[t]{2}{*}{ Treatments } & \multicolumn{6}{|c|}{ Germination $\%$ of Quality Protein Maize } \\
\hline & & 2 Month & 4 Month & 6 Month & 8 Month & 10 Month & 12 Month \\
\hline 1 & S1M1 & 95 & 96 & $94^{\mathrm{a}}$ & $95^{\mathrm{a}}$ & $94^{\mathrm{a}}$ & $89^{\mathrm{a}}$ \\
\hline 2 & S1M2 & 95 & 96 & $97^{\mathrm{a}}$ & $96^{\mathrm{a}}$ & $88^{\mathrm{ab}}$ & $92^{\mathrm{a}}$ \\
\hline 3 & S2M1 & 96 & 95 & $95^{\mathrm{a}}$ & $88^{\mathrm{ab}}$ & $84^{\mathrm{ab}}$ & $63^{\mathrm{b}}$ \\
\hline 4 & $\mathrm{~S} 2 \mathrm{M} 2$ & 96 & 95 & $97^{\mathrm{a}}$ & $83^{\mathrm{b}}$ & $72^{\mathrm{b}}$ & $69^{\mathrm{b}}$ \\
\hline 5 & S3M1 & 96 & 96 & $98^{\mathrm{a}}$ & $95^{\mathrm{a}}$ & $94^{\mathrm{a}}$ & $94^{\mathrm{a}}$ \\
\hline 6 & S3M2 & 96 & 96 & $96^{\mathrm{a}}$ & $96^{\mathrm{a}}$ & $95^{\mathrm{a}}$ & $95^{\mathrm{a}}$ \\
\hline 7 & S4M1 & 94 & 93 & $82^{\mathrm{b}}$ & $53^{\mathrm{c}}$ & $37^{\mathrm{c}}$ & $29^{\mathrm{d}}$ \\
\hline 8 & S4M2 & 95 & 93 & $85^{\mathrm{b}}$ & $65^{\mathrm{c}}$ & $41^{\mathrm{c}}$ & $38^{\mathrm{c}}$ \\
\hline 9 & S5M1 & 96 & 95 & $95^{\mathrm{a}}$ & $94^{\mathrm{ab}}$ & $96^{\mathrm{a}}$ & $95^{\mathrm{a}}$ \\
\hline 10 & S5M2 & 96 & 94 & $96^{\mathrm{a}}$ & $96^{\mathrm{a}}$ & $94^{\mathrm{a}}$ & $96^{\mathrm{a}}$ \\
\hline \multicolumn{2}{|c|}{ F-value } & 0.219 & 0.239 & 0.013 & $<0.001$ & $<0.001$ & $<0.001$ \\
\hline \multicolumn{2}{|c|}{ LSD $(0.05)$} & 1.726 & 2.989 & 8.034 & 11.93 & 18.89 & 7.77 \\
\hline \multicolumn{2}{|c|}{ CV (\%) } & 0.8 & 1.4 & 3.9 & 6.4 & 11.1 & 4.6 \\
\hline \multicolumn{2}{|c|}{ Grand mean } & 96 & 95 & 94 & 84 & 77 & 76 \\
\hline \multicolumn{2}{|c|}{$\operatorname{SEM}( \pm)$} & 0.775 & 1.342 & 3.606 & 5.35 & 8.48 & 3.48 \\
\hline \multicolumn{2}{|c|}{$F$ test } & NS & NS & * & $* *$ & $* *$ & ** \\
\hline
\end{tabular}


Journal of Maize Research and Development (2017) 3 (1):77-85

ISSN: 2467-9291 (Print), 2467-9305 (Online)

DOI: http://dx.doi.org/10.3126/jmrd.v3i1.18924

Means followed by the same alphabets on superscript are not significant by Fisher LSD Method in $95 \%$ Confidence. ${ }^{*}(\mathrm{p} \leq 0.05),{ }^{* *}(\mathrm{p} \leq 0.01)$, (NS-Non-Significant)

Many hermetic research corroborated on this findings. Germination above $80 \%$ in maize also recorded up to 15 months in 500 gauge plastic bags which as stored in 12\% and 8\% MC (Mettananda et al., 2001).

Fig 3: Correlation of Electrical conductivity and germination in QPM seed from various containers and MC in one year storage in Khumaltar, 2015-2016.

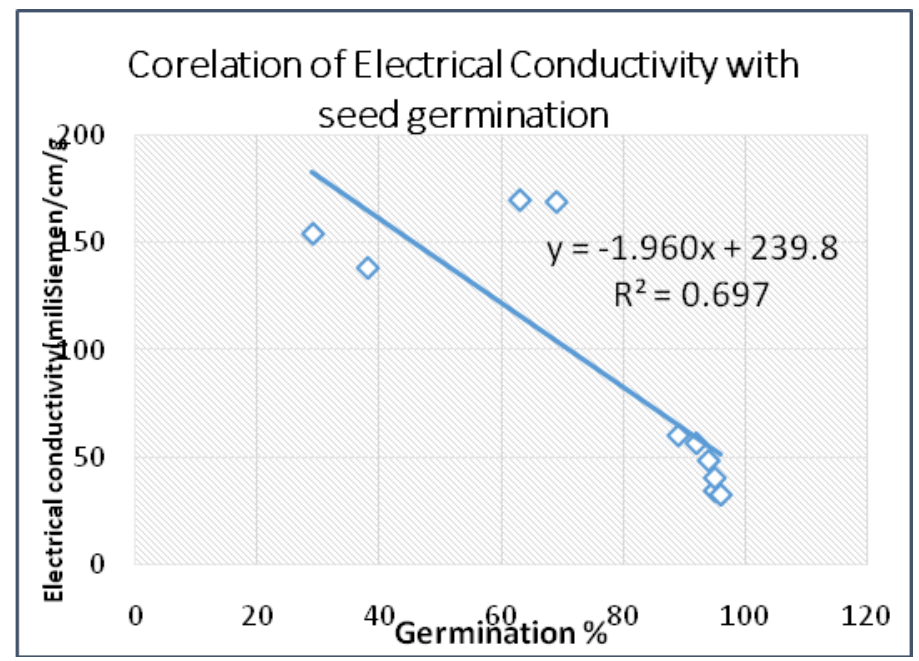

A reciprocal relationship was obtained by plotting the electrical conductivity and germination of 12-months storage QPM-1 seed sample. Irrespective of other things, $69.7 \%$ germination value was found indirectly proportional to EC reading. Similar trend with rather good results in soybean $(r=-0.89$ and -0.92$)$ (Oliveira et al., 1984); soybean with $\mathrm{r}=-$ 0.67 to -0.79 (Yaklich et al., 1979), long bean with correlation coefficient -0.80 and -0.86 (Abdullah et al., 1991);in

Phaseolus with $\mathrm{r}=-0.80$ and -0.87 (Powellet al., 1986); in cabbage and cauliflower with $\mathrm{r}^{2}$ value 0.79 to 0.96 (Mirdad et al., 2006) have been found documented (Figure 3).

On the moisture content, for one year period, each data showed highly significant variation in means both in structures and moisture content. Generally, the hermetic containers were found with less fluctuated figures than non- hermetic containers, viz., Fertilizer sack (S2) and Earthen pot (S4) as compared with the initial moisture contents (M1\& M2) 11\% and 9\%. The moisture contents on these containers were found fluctuated with the storage condition as they are highly influenced by the external environmental conditions. The detailed data of each treatment is presented in table 2. Similar supported works revealed in hermetic 500 gauge plastic bags, where $12 \% \mathrm{MC}$ was just increased to $12.5 \%$ and $13 \%$ in 10 month and 15 month storage in ambient room temperature in Srilanka (Mettananda et al., 2001). Similarly, Data logger placed inside the hermetic bags-PICS and woven polypropylene bag did not get fluctuate on its internal environmental profiles in two different locations and found no penetration of moisture too. (Lane \& Woloshuk, 2017). 
Journal of Maize Research and Development (2017) 3 (1):77-85

ISSN: 2467-9291 (Print), 2467-9305 (Online)

DOI: http://dx.doi.org/10.3126/jmrd.v3i1.18924

Table 2. Effects of seed moisture content and storage structure on moisture content of QPM-1 for yearlong storage in SSTD, Khumaltar, 2016.

\begin{tabular}{|c|c|c|c|c|c|c|c|}
\hline \multirow{2}{*}{$\begin{array}{l}\text { Ent } \\
\text { No }\end{array}$} & \multirow[t]{2}{*}{ Treatments } & \multicolumn{6}{|c|}{ Moisture \% of Quality Protein Maize } \\
\hline & & 2 Month & 4 Month & 6 Month & 8 Month & 10 Month & 12 Month \\
\hline 1 & S1M1 & $10.41^{\mathrm{c}}$ & $9.93^{\mathrm{d}}$ & $9.65^{c}$ & $10.3^{\mathrm{c}}$ & $10.23^{\mathrm{cd}}$ & $10.24^{\mathrm{cd}}$ \\
\hline 2 & S1M2 & $9.43^{\mathrm{d}}$ & $8.87^{\mathrm{e}}$ & $8.10^{\mathrm{e}}$ & $8.97^{\mathrm{c}}$ & $9.46^{\mathrm{d}}$ & $9.88^{\mathrm{de}}$ \\
\hline 3 & S2M1 & $12.3^{\mathrm{a}}$ & $12.08^{\mathrm{a}}$ & $12.07^{\mathrm{a}}$ & $12.82^{\mathrm{ab}}$ & $12.74^{\mathrm{b}}$ & $13.06^{\mathrm{b}}$ \\
\hline 4 & $\mathrm{~S} 2 \mathrm{M} 2$ & $11.76^{\mathrm{b}}$ & $10.9^{\mathrm{b}}$ & $11.64^{\mathrm{ab}}$ & $12.91^{\mathrm{ab}}$ & $13.97^{\mathrm{ab}}$ & $13.59^{\mathrm{ab}}$ \\
\hline 5 & S3M1 & $10.38^{\mathrm{c}}$ & $9.93^{\mathrm{d}}$ & $9.49^{\mathrm{cd}}$ & $9.51^{\mathrm{c}}$ & $11.07^{\mathrm{c}}$ & $10.97^{\mathrm{c}}$ \\
\hline 6 & $\mathrm{~S} 3 \mathrm{M} 2$ & $9.38^{\mathrm{d}}$ & $9.14^{\mathrm{e}}$ & $8.25^{\mathrm{e}}$ & $9.17^{\mathrm{c}}$ & $9.79^{\mathrm{cd}}$ & $9.66^{\mathrm{de}}$ \\
\hline 7 & S4M1 & $11.98^{\mathrm{ab}}$ & $12.02^{\mathrm{a}}$ & $12.31^{\mathrm{a}}$ & $14.1^{\mathrm{a}}$ & $14.56^{\mathrm{a}}$ & $14.32^{\mathrm{a}}$ \\
\hline 8 & S4M2 & $10.05^{\mathrm{c}}$ & $10.43^{\mathrm{c}}$ & $11.07^{\mathrm{b}}$ & $12.37^{\mathrm{ab}}$ & $13.07^{\mathrm{b}}$ & $13.0^{\mathrm{b}}$ \\
\hline 9 & S5M1 & $10.35^{\mathrm{c}}$ & $9.66^{\mathrm{d}}$ & $9.69^{c}$ & $9.72^{\mathrm{c}}$ & $9.90^{\mathrm{cd}}$ & $10.08^{\text {cde }}$ \\
\hline 10 & S5M2 & $9.01^{\mathrm{d}}$ & $9.14^{\mathrm{e}}$ & 8.31 & $9.17^{\mathrm{c}}$ & $9.29^{\mathrm{d}}$ & $9.22^{\mathrm{e}}$ \\
\hline \multicolumn{2}{|c|}{ F-value } & $<0.001$ & $<0.001$ & $<.001$ & $<0.001$ & $<0.001$ & $<0.001$ \\
\hline \multicolumn{2}{|c|}{$\operatorname{LSD}(0.05)$} & 0.51 & 0.384 & 0.8481 & 1.556 & 1.46 & 0.937 \\
\hline \multicolumn{2}{|c|}{$\mathrm{CV}(\%)$} & 2.2 & 1.7 & 3.8 & 6.5 & 5.7 & 3.7 \\
\hline \multicolumn{2}{|c|}{ Grand mean } & 10.50 & 10.21 & 9.96 & 10.80 & 11.41 & 11.40 \\
\hline \multicolumn{2}{|c|}{$\operatorname{SEM}( \pm)$} & 0.227 & 0.172 & 0.381 & 0.698 & 0.665 & 0.42 \\
\hline \multicolumn{2}{|c|}{ F-test } & $* *$ & $* *$ & $* *$ & $* *$ & $* *$ & $* *$ \\
\hline
\end{tabular}

Means followed by the same alphabets on superscript are not significant by Fisher LSD Method in $95 \%$ Confidence. $*(\mathrm{p} \leq 0.05),{ }^{* *}(\mathrm{p} \leq 0.01)$, (NS-Non-Significant)

\section{CONCLUSION}

The study found that Hermetic storage containers, PICS bag, Super grain bag, and Metal-bin corroborated superiority over fertilizer sack and earthen pot for seed storage and retaining quality in both germination and vigor in lower moisture content for yearlong storage in maize. Hence, maintaining low $\mathrm{MC}$ and using hermetic devices significantly contributes in maintaining the viability and vigor of seeds in sub-tropical environmental condition. Mass utilization of such containers for seeds storage not only protect seeds from biotic and abiotic deterioration but also helps in conserving seeds for two consecutive growing seasons that eventually reduces the demand and procurement of seeds in successive season. Moreover, EC test for rapid appraisal of seeds lot can be an effective tool that can validate the seed quality in significantly shorter period of time with limited resources.

\section{ACKNOWLEDGEMENTS}

This research was funded by Nepal Agricultural Research Council, Seed Science and Technology Division, Khumaltar, Lalitpur, Nepal. 
Journal of Maize Research and Development (2017) 3 (1):77-85

ISSN: 2467-9291 (Print), 2467-9305 (Online)

DOI: http://dx.doi.org/10.3126/jmrd.v3i1.18924

\section{AUTHOR CONTRIBUTIONS}

R. A. proposed the project. T.B.G. designed the experiment. S. K. collected the data. G. B. and J. S. analyzed the data and wrote the paper, and revised the article for the final approval of the version to be published.

\section{CONFLICTS OF INTEREST}

The authors declare that there is no conflict of interest.

\section{REFERENCES}

Abba, J. E., \& Lovato, A. (1999). Effect of seed storage temperature and relative humidity on maize (Zea mays L.) seed viability and vigor. Seed Science and Technology, 27, 101-114.

Abdullah, W. D., Powell, A. A., \& Matthews, S. (1991). Association of differences in seed vigor in long bean (Vigna sesquipedalis) with testa colour and imbibition damage. The Journal of Agricultural Science, 116(2), 259-264. https://doi.org/10.1017/S0021859600077662

Adetumbi, A.J., Odiyi, A.C., Olakojo, S. \& Asebisi, M.A. (2009) Effect of storage materials and environments on drying and germination quality of maize (Zea mays L) seed. Electronic Journal of Environmental, Agricultural and Food Chemistry 8(11):1140-1149.

Adriana, L., Tassi, W., Santos, J.F.D., \& Panizzi, R.D.C. (2012) Seed-borne pathogens and electrical conductivity of soybean seeds. Sci. Agric. 69:19-25.

AOSA (1983) Seed vigor testing handbook. East Lasing: Association of Official Seed Analysts (AOSA), 93p.

Bewley, J.D., \& Black, M. (1994). Seeds Physiology of development and germination. New York: Plenum Press, 444p.

Egli, D.B., \& Tekrony, D.M (1996) Seedbed conditions and prediction of field emergence of soybean seed. Journal of Production Agriculture, 9, 365-370

Bhandari, G. S, Achhami, B.B., Karki, T. B., Bhandari, B., \& Bhandari, G. (2015). Survey on maize post-harvest losses and its management practices in the western hills of Nepal. Journal of Maize Research and Development 1(1):98-105. http://dx.doi.org/10.3126/jmrd.v1i1.14247

GC, Y. (2006). Efficacy of Indigenous Plant Materials and Modified Storage Structures to Insect Pests of Maize Seed during On-Farm Storage. J. Inst. Agric. Anim. Sci., 27, 69-76.

Harrington, J.F. (1960). Thumb rubs of drying seed. Crops \& soils Publisher. 13, 16-17.

ISTA (2011). International Rule for Seed Testing. The international seed testing association (ISTA), Zurichstr. 50, Switzerland. Pp15A-4.

Joshi, G.R., (2015) Seed Enterprise Development in Nepal: Opportunities and Challenges. Thematic Paper for Seed Submit, 2015

KC Govind, Karki T.B., Shrestha J. and Achhami B.B. (2015) Status and prospects of maize research in Nepal. Journal of Maize Research and Development, 1(1), 19. http://dx.doi.org/10.3126/jmrd.v1i1.14239

Lane, B., \& Woloshuk, C. (2017). Impact of storage environment on the efficacy of hermetic storage bags. Journal of Stored Products Research, 72, 8389.https://doi.org/10.1016/j.jspr.2017.03.008 
Journal of Maize Research and Development (2017) 3 (1):77-85

ISSN: 2467-9291 (Print), 2467-9305 (Online)

DOI: http://dx.doi.org/10.3126/jmrd.v3i1.18924

Matthews, S. \& Powell, A. (2006) Electrical Conductivity Vigor Test: Physiological Basis and Use. Seed Testing International. No 131.

Mettananda, K.A., Weerasena, S.L., \& Liyanage, Y. (2001) Effects of Storage Environment, Packing material, and Seed Moisture content on Storability of Maize (Zea mays L.) Seeds. Annals of the Sri Lanka Department of Agriculture, 3, 131-142.

Mirdad, Z., Powell, A.A., \& Matthews, S. (2006). Prediction of germination in artificially aged seeds of Brassica spp using the bulk conductivity test. Seed Science and Technology

Oliveira, M. de A., Matthews, S., \& Powell, A.A., (1984) The role of split seed coats in determining seed vigour in commercial seed lots of soybean, as measured by the electrical conductivity test. Seed Science and Technology, 12, 659-668.

Powell, A. A. (1988). Seed vigour and field establishment.[A review]. Advances in research and technology of seeds.

Powell, A.A. (1988) Seed vigor and field establishment. Journal of Advance Research and Technology in Seeds. 11, 29-80.

Powell, A.A., Oliveira, M. de A., \& Matthews, S. (2009) Seed vigour in cultivars of dwarf French bean (Phaseolus vulgaris) in relation to the colour of the testa. Journal of Agricultural Science, $\quad$ Cambridge, $\quad 109, \quad 419$ 425.https://doi.org/10.1017/S0021859600064030

Sherpa, L., Ojha, N.G., \& Sharma, A.R., (1997). Why farmers adopt or reject Agricultural Technology: A case study of improved maize and wheat varieties in the Ex- local largest area of Pakhribas Ag. Center at Dhankuta. PAC Technical paper no 177.

Tekrony, D.M., \& Hunter, J.L. (1995). Effect of seed maturation and genotype on seed vigor in maize. Crop Science, 35, 857-862.

Vieira, R.D., Paiva, A. J.A., \& Perecin, D. (1994) Electrical conductivity and field performance of soybean seeds. Seed Technology, 21, 15-24,

Yaklich, R.W., Kulik, M.M., \& Anderson, J.D., (1979) Evaluation of vigor tests in soybean seeds: relationship of ATP, conductivity, and radioactive tracer multiple criteria tests to field performance. Crop Science, 19, 806-810. 